\title{
HUBUNGAN PERKEMBANGAN PSIKOSOSIAL DENGAN PRESTASI BELAJAR ANAK USIA SEKOLAH
}

\author{
Ulfah Ainul Khasanah, Livana PH*, Novi Indrayati \\ Program Studi Ilmu Keperawatan, Sekolah Tinggi Ilmu Kesehatan Kendal \\ Email: livana.ph@gmail.com
}

\begin{abstract}
ABSTRAK
Perkembangan psikososial merupakan perubahan dan kestabilitas dalam emosi, kepribadian dan hubungan sosial yang dapat berpengaruh terhadap fugsi kognitif dan fisik pada anak usia sekolah. anak usia sekolah (6-12 tahun) berada dalam industry vs inferior dimana perkembangan psikososial anak akan mampu menghasilkan keterampilan atau karya, berinteraksi dan berprestasi. Tujuan: Penelitian ini bertujuan untuk mengetahui hubungan perkembangan psikososial dengan prestasi belajar anak usia sekolah di SD N 01 Patukangan Kendal. Penelitian ini merupakan penelitian kuantitatif. Sampel sebanyak 100 responden. Teknik penelitian menggunakan Total Sampling. Variabel dependen penelitian ini adalah perkembangan psikososial yang diukur dengan kuesioner, dan variabel independen adalah prestasi belajar yang diukur dengan nilai rata-rata raport siswa. Analisis penelitian ini menggunakan Kendall Tau $b$ yang dilakukan selama 5 hari di SD N 01 Patukangan Kendal. Hasil penelitian menunjukkan Tidak ada hubungan antara perkembangan psikososial dengan prestasi belajar anak usia sekolah di SD N 01 Patukangan Kendal dengan hasil $\rho=0,600>0,05$.
\end{abstract}

Kata kunci: anak usia sekolah, perkembangan psikososial, prestasi belajar

\section{THE RELATIONSHIP OF PSYCHOSOCIAL DEVELOPMENT WITH SCHOOL-AGE LEARNING ACHIEVEMENT}

\begin{abstract}
Psychosocial development is a change and stability in emotions, personalities and social relationships that can affect cognitive and physical function in school-age children. school age children (6-12 years) are in the industry vs inferior where the child's psychosocial development will be able to produce skills or work, interact and achieve. This study aims to determine the relationship of psychosocial development with school-age learning achievement in SD N 01 Patukangan Kendal. This research is quantitative research. Samples of 100 respondents. The research technique uses total sampling. The dependent variable of this study is psychosocial development as measured by a questionnaire, and the independent variable is learning achievement as measured by the average value of student report cards. The analysis of this study used Kendall Tau $b$ which was conducted for 5 days in SD N 01 Patukangan Kendal. The results showed there was no relationship between psychosocial development and learning achievement of school-aged children in SD N 01 Patukangan Kendal with results $\rho=0,600>0,05$.
\end{abstract}

Keywords: school age ana, psychosocial development, learning achievemen

\section{PENDAHULUAN}

Perkembangan manusia memiliki tujuan untuk memahami tentang bagaimana proses berkembang pada usia 6-12 tahun atau sering disebut masa anak usia sekolah. Usia sekolah membuat anak mendapatkan dasardasar pengetahuan untuk keberhasilan penyesuaian diri, dimana anak akan memiliki sifat santun untuk mencapai tujuannya kedepan yang berujung pada kemandirian, bertanggung jawab, dan berhubungan baik dengan teman sebaya dan orang lain (Allen, 2010). Berdasarkan teori perkembangan menurut Yusuf (2004) menyatakan bahwa hal itu merupakan pencapaian yang matang dalam hubungan sosial, yang artinya perkembanagn sosial sebagai proses belajar untuk menyesuaikan perilaku sosial kedalam 
norma-norma kelompok sosial. Dasar perkembangan secara teoritik untuk anak, yaitu perkembangan mental diantaranya perkembangan kognitif, perkembangan bahasa, perkembangan konsep diri serta perkembangan kepribadian mencakup didalamnya perkembangan psikososial.

Menurut (Wong, 2008) Perkembangan psikososial adalah perubahan yang terjadi pada kepribadian, emosi serta hubungan sosial. Pada tahapan ini anak lebih mudah memahami dari segi internal dibanding eksternal sehingga dapat memilih apa yang baik baginya.Anak mulai memecahkkan masalahnya sendiri dan mulai mengidentifikasi terhadap hal baik yang menarik perhatiannya (Perry \& Potter, 2009). Data dari Riskesdas tahun 2013, disebutkan lebih dari 14 juta jiwa penduduk indonesia yang diantaranya adalah anak-anak menderita gangguan perkebangan psikosial emosional. Gangguan perkembangan di Sulawesi Tengah yaitu sebesar $11,6 \%$, sedangkan di Jawa Tengah sebesar 4,7\% (Kemenkes, 2016).

Perkembangan psikososial yang normal yaitu anak memiliki personality yang baik, memiliki keberanian, kooperatif, mampu menerima pendapat dan kepercayaan pada diri sendiri dan orang lain. Sebaliknya jika anak memiliki perkembangan psikososial yang kurang baik atau meyimpang, anak akan memiliki sifat negatif seperti tidak percaya diri, mengasingkan diri dan merasa rendah diri (Riyadi, 2009). Faktor yang dapat mempengaruhi perkembangan psikososial antara lain stimulasi, komunikasi ibu dan anak, status kesehatan, lingkungan dan kelompok teman sebaya (Soetjiningsih, 2014).

Erikson (1968 dalam Wong, 2008) mengatakan bahwa anak usia sekolah (6-12 tahun) berada dalam industry $v$ s inferior dimana perkembangan psikososial anak akan mampu menghasilkan keterampilan atau karya, berinteraksi dan berprestasi. Prestasi diartikan sebagai suatu tingkatan keberhasilan belajar. Prestasi ini diperoleh dengan mengevaluasi hasil belajar siswa. Prestasi belajar adalah penguasaan pengetahuan dan keterampilan yang dikembangkan oleh mata pelajaran, lazimnya ditujukan dengan nilai tes atau angka yang di berikan oleh guru.

Prestasi belajar siswa bukan karena kecerdasan siswa saja, akan tetapi ada faktor lain yang dapat mempengaruhi prestasi belajar tersebut. Menurut Syah (2011) menyatakan bahwa secara global faktorfaktor yang mempegaruhi prestasi belajar dibedakan menjadi tiga macam, yakni: faktor internal (faktor fisiologis, faktor psikologis), faktor eksternal (faktor keluarga, lingkungan, masyarakat), dan faktor pendekatan belajar. Hal tersebut sama dengan penelitian yang dilakukan oleh Lovena (2013), konteks dalam belajar dapat dipengaruhi oleh lingkunga, sekolah, keluarga dan teman sebaya.

Hasil studi yang pernah dilakukan oleh International Associationfor the Evaluation of Education Achievemen (IEA) melalui program Highlighstfrom Trends in Mathematic and Science Study (TIMSS) pada tahun 2011 bahwa prestasi siswa sekolah dasar di indonesia berada di peringkat ke-38 dari 42 negara dalam hal prestasi sains. Ratarata skor tes membaca anak sekolah dasar 75,5 (Hongkong), 74,0 (Singapura) dan 51,7 (Indonesia). Anak Indonesia hanya mampu menguasai 30\% (TIMSS, 2011)

Pencapaian prestasi belajar siswa sekolah dasar dapat dilihat dari hasil Uji Kompetensi. Kementerian pendidikan dan kebudayaan Indonesia mengumumkan pada tahun 2015, terdapat 5 provinsi yang menduduki nilai rata-rata terendah, yaitu Maluku (34,5), Maluku Utara (34,8), Kalimantan Barat $(35,40)$, Kalimantan Tengah $(35,5)$ dan Jambi $(35,7)$. Hal itu dikarenakan tingkat daya saing dan sumber daya manusia kurang maksimal, selain itu keberadaan daerah tinggal juga berpengaruh. Berbeda dengan daerah yang lebih maju memiliki sumber daya manusia yang lebih baik. Daerah yang menduduki nilai tertinggi yaitu Yogyakarta(50,1), Jakarta $(49,2)$, Bali $(48,9)$, Jawa Timur $(47,1)$, Jawa Tengah $(45,2)$ (Kementerian Pendidikan dan Kebudayaan, 2015). Kendal menduduki 
peringkat ke-18 se-Jawa Tengah (Dinas Pendidikan Jateng, 2016). Tujuan penelitian ini yaitu untuk mengetahui hubungan perkembangan psikososial dengan prestasi belajar anak usia sekolah di SD N 01 Patukangan Kendal. Jenis penelian ini adalah penelitian kuantitatif.

Hasil wawancara dengan 10 siswa, terdapat perbedaan perkembangan psikososial dan prestasi belajar. 3 dari 10 siswa mengalami penyimpangan. Terdapat 1 siswa menyimpang berupa merokok disekolah dengan hasil prestasi belajar rata-rata cukup yaitu dengan nilai 76 . Penyimpangan yang lain yaitu siswa sering di bully dan di ejek apabila penampilannya berbeda dengan teman lainnya.

\section{METODE}

Jenis penelitian ini adalah penelitian kuantitatif degan pendekatan yang digunakan dalam penelitian ini adalah deskriptif korelasional. Populasi dalam penelitian ini adalah semua anak usia sekolah yang menduduki kelas 4, 5 dan 6 di SD N 01 Patukangan Kendal, dengan sampel sebanyak 100 responden. Teknik pengambilan sampel yaitu Total Sampling. Instrumen yang digunakan dalam penelitian ini adalah kuesioner perkembangan psikososial dan lembar observasi nilai rata-rata raport. Data dianalisis menggunakan uji Kendall Tau $b$.

\section{HASIL}

Hasil analisis data hubungan perkembangan psikososial anak usia sekolah di SD N 01 Patukangan Kendal berdasarkan karakteristik responden usia 9 tahun terdapat 27 responden, 10 tahun terdapat 35 responden, 11 tahun terdapat 36 responden, dan usia 12 tahun terdapat 2 responden.

Tabel 1.

Perkembangan psikososial anak usia sekolah $(\mathrm{n}=100)$

\begin{tabular}{lcc}
\hline Perkembangan psikososial & $\mathrm{f}$ & $\%$ \\
\hline Normal & 69 & 69 \\
Menyiimpang & 31 & 31 \\
\hline
\end{tabular}

Tabel 2.

Prestasi belajar anak usia sekolah $(\mathrm{n}=100)$

\begin{tabular}{llc}
\hline Prestasi belajar & $\mathrm{f}$ & $\%$ \\
\hline Baik & 32 & 32 \\
Cukup & 66 & 66 \\
Kurang & 2 & 2 \\
\hline Tabel 2 menunjukkan bahwa Perkembangan & Berdasarkan hasil analisis data pada Tabel 3 \\
psikososial anak usia sekolah mayoritas & menunjukkan bahwa Prestasi belajar siswa \\
memiliki perkembangan psikososial yang & mayoritas dalam kategori cukup. Hasil \\
normal. & analisis data Hubungan Perkembangan \\
& Psikososial anak usia sekolah di SD N 01 \\
& Patukangan Kendaldengan uji Kendall Tau b \\
& sebagai berikut:
\end{tabular}

Tabel 3.

Hubungan Perkembangan Psikososial anak usia sekolah $(n=100)$

\begin{tabular}{llcc}
\hline & & $\begin{array}{c}\text { Perkembangan } \\
\text { Psikososial }\end{array}$ & Prestasi Belajar \\
\hline Perkembangan Psikososial & Correlation coefficient & .1000 & .052 \\
& Sig. 2 (tailed) & & .600 \\
\hline Prestasi Belajar & Correlation coefficient & .052 & 1000 \\
& Sig. 2 (tailed) & 600 &
\end{tabular}


Berdasarkan hasil analisis hubungan perkembangan psikososial dengan prestasi belajar anak usia sekolah. didapatkan hasil $\rho$ value $=0,600$ ( $\rho$ value $>0,05)$, sehingga dapat diartikan bahwa tidak ada hubungan antara perkembangan psikososial dengan prestasi belajar anak usia sekolah.

\section{PEMBAHASAN}

Berdasarkan hasil analisis data dapat diketahui bahwa sebanyak $69,0 \%$ responden memiliki perkembangan psikososial normal dan $31,0 \%$ responden memiliki perkembangan psikososial menyimpang. Dari hasil tersebut menunjukkan bahwa mayoritassiswa di SD N 1 Patukangan memiliki perkembangan psikososial yang normal. Penelitian Keliat dkk, (2015), bahwa anak usia sekolah yang memiliki perkembangan psikososial yang normal, yaitu anak mampu bertanggung jawab dan menyelesaikan tugas yang diberikan (disekolah maupun dirumah), memiliki rasa bersaing (Kompetitif), memiliki hoby; menggambar, membaca buku bercerita, bersepeda Serta suka berkelompok dan memiliki sahabat. Berdasarkan hasil penelitian Gunarsa dan Singgih (2008), bahwa proses perkembangan yang terjadi dalam diri seorang anak serta apa yang dialami dan diterima selama masa anak-anak, secara sedikit demi sedikit membuat anak tumbuh menjadi lebih dewasa

Berdasarkan hasil studi analisis dapat diketahui bahwa Mayoritas anak usia sekolah di SD N 01 Patukangan memiliki prestasi belajar yang cukup yaitu $66,0 \%, 32,0 \%$ memiliki prestasi belajar yang baik, dan 2,0\% memiliki prestasi belajar yang kurang. Penelitian Hidayat (2012), bahwa perkembangan anak usia sekolah ditunjukkan dengan sikap yang selalu berusaha dan mengedepankan keinginannya dalam mencapai prestasinya, sehingga anak rajin melakukan sesuatu, misalnya bertanya kepada guru terkait pelajara yang tidak dipahami, mendengarkan dengan baik ketika guru menjelaskan dan merasa gagal jika nilai ujiannya jelek. Akan tetapi apabila harapan anak tidak tercapai, anak akan merasa rendah diri. Sejalan dengan Penelitian Slameto (2010), yang menyatakan bahwa dalam proses belajar, guru memiliki peran penting untuk mendorong siswa, membimbing, dan memberikan fasilitas pembelajaran untuk menjadikan kegiatan belajar mengajar yang efisien, yang hasilnya dapat dilihat dari evaluasi akhir prestasi belajar siswa yang optimal.

Hasil Penelitian terhadap perkembangan psikososial anak usia sekolah di SD N 01 Patukangan terdapat 2 responden yang memiliki nilai prestasi kurang. Sebanyak $62,0 \%$ siswa merasa takut dan berkeringat ketika disuruh tampil di depan kelas, 54,0\% siswa sering terlambat datang ke sekolah, dan 48,0\% siswa takut mengeluarkan pendapat jika ditertawakan oleh teman-temannya. Sehingga dapat disimpulkan bahwa perkembangan psikososialnya menyimpang. Sedangkan siswa yang perkembangan psikososialnya normal 49,0\% siswa mampu berkomunikasi baik dengan guru, 46,0\% siswa tidak mencontek saat ujian karena percaya diri dan 50,0\% siswa mematuhi peraturan dan disiplin. Seperti yang diungkapkan Lovena (2013), bahwa prestasi belajar atau hasil belajar perlu dievaluasi, hal itu bertujuan untuk melihat apakah pembelajaran yang diberikan sudah efektif untuk memperoleh hasil belajar itu sendiri.

Berdasarkan hasil analisis hubungan perkembangan psikososial dengan prestasi belajar anak usia sekolah. didapatkan hasil $\rho$ value $=0,600$ ( $\rho$ value $>0,05)$, disimpulkan bahwa tidak ada hubungan antara hubungan perkembangan psikososial dengan prestasi belajar anak usia sekolah. Penelitian Suharno (2011), juga mengatakan tidak ada pengaruh disiplin belajar terhadap prestasi belajar pada kelas 5 SD Islam Darul Falah Genuk diperoleh nilai $_{\mathrm{rxy}}=0,45$.

\section{SIMPULAN DAN SARAN \\ Simpulan}

Anak usia sekolah mayoritas memiliki perkembangan psikososial yang normal dengan Prestasi belajar rata-rata cukup. Hasil analisis menunjukkan Tidak ada hubungan antara perkembangan psikososial dengan prestasi belajar anak 
usia sekolah di dengan hasil $\rho=0,600>$ 0,05 .

\section{Saran}

Peneliti selanjutnya agardapat meneliti faktor-faktor yang membuat anak takut ketika tampil di kelas sehingga diketahui perkembangan psikososial anak yang menyimpang.

\section{DAFTAR PUSTAKA}

Allen, E. K., \& Marotz, L. (2010). Profil Perkembangan Anak Pelahiran Hingga Usia 12 Tahun Edisi Kelima. Jakarta: PT. Indek.

Dinas Pendidikan Jateng. (2016). Hasil Seleksi Tahap 1 OSN SD Tingkat Provinsi Jawa Tengah 2016. Diakses pada tanggal 1 November 2016 melalui:http://pdk.jatengprov.go.id/ main/read/1/dikdas/1004/.

Gunarsa, S. D. (2008). Psikologi Perkembangan Anak dan Remaja. Jakarta: PT BPK gunung mulia.

Hidayat. A.A.A. (2012). Metode PenelitianKeperawatan\& Teknik Analisis Data. Jakarta: SalembaMedika

Kemenkes RI. (2016). Pedoman Pelaksanaan Stimulasi, Deteksi, dan Intervensi Dini Tumbuh Kembang Anak di Tingkat Pelayanan Kesehatan Dasar, Jakarta: Kemenkes RI.

Kementerian pendidikan dan kebudayaan. (2015). Laporan Kinerja 2015. Jakarta. Diakses tanggal 1 November 2016 melalui: http://www.kemdikbud.go.id/main/ uploadsKEMENDIKBUD\%202015

Lovena, Anestesya. (2013). Hubugan Antara Perkembangan Psikososial Anak Terhadap Hasil Belajar
Bahasa Indonesia Siswa Kelas 4 di SD N 65 Kota Bengkulu. Skripsi. Fakultas Keguruan dan Ilmu Pendidikan. Universitas Bengkulu.

Meland, a.t. Kaltvedt (2015). Toodlers Master Everyday Activities in Kindergarten: a Gender Perspective. European Early Childhood Education Research Journal.

Nasution. Aiayah Hayani. (2017). Perkembangan Psikososial Anak Usia Sekolah di SD N 060922 Kelurahan Tanjung Rejo Kecamatan Medan Sunggal.

Potter, P. A., \& Perry, A G., (2010). Fundamental Keperawatan Edisi Ketujuh Edisi Satu. Elsevier Singapore: Salemba Medika

Riyadi, S. \& Sukarmin. (2009). Asuhan keperawatan Pada Anak Edisi Pertama. Yogyakarta: Graha Ilmu

Santrock, J. W., (2011). Masa Perkembangan Anak Edisi Kesebelas. Jakarta: Salemba Humanika

Pendidikan. Unibversitas Negeri Yogyakarta.

Sen, s., \& kavlak. (2012). Itransgeneration Attachment in Manisa Turkey. Contemporary Nurse, 41(1), 126-132.

Shaffer, K.A. 2005. On The Nature and Function of Emoticon: A Component Process Approach. In K. R. Scherer \& P.E Ekman (Eds), Approachs to Emoticon (PP.293317). Hillsdale, N.J.: Erlbaum

Slameto. (2010). Belajar dan Faktorfaktor yang Mempengaruhinya. Jakarta: Rineka Cipta 
Slameto. (2010). Pola Asuh Orang Tua dalam Membantu Anak Mengmbangkan Disiplin Diri. Jakarta: Rineka Cipta.

Suharno. (2011). Pengaruh Disiplin Belajar Terhadap Prestasi Belajar Kelas 5 di SD Islam Darull Falah Genuk Semarang. Skripsi. IAIN wali songo

Suwargarini, Ria \& Fatkhul mubin. (2014). Gambaran Psikologis: Konsep Diri Pada Anak Usia Sekolah Dasar di Wilayah Banjir Rob Kelurahan Bandarharjo Semarang Utara. Jurnal keperawatan Anak. Vol 2. No 2.

Syah. (2011). Psikologi Belajar. Jakarta : Rajawali Pres.

Trends in Mathematic and Science Study (TIMSS). (2011). Highlights from TIMSS 2011 The South african perspective. Human sciences research council. Diakses tanggal 8 Desember 2016 melalui: http://www.hsrc.ac.za/uploads/../TI MSSHighlights2012Dec7final.pdf

Wong, D (2010). Buku Ajar Keperawatan Pediatric (Wong's Essential of Pediatric Nursing). Edisi 6. Jakarta : EGC.

Yusuf, S. (2004). Psikologi Perkembangan Anak dan Remaja. Bandung: Rosdakarya

Zulkarnain., Endah Rahmawati, \& Ellyna. (2016). Hubungan Pola Asuh Ayah dengan Perilaku Disiplin Anak di RA Muslimat Kota Malang. Journal Pendidikan Non vormal. Vol 10. No 2. 